\title{
2 \\ Towards Smart, Benign Urban Water Infrastructure
}

\section{William James}

This chapter was also presented recently in Chicago by the author. It advances ideas for reducing the unsustainability of infrastructure, in the belief that true sustainability of water systems of large cities is unfortunately implausible. Our drinking water, wastewater, and storm water infrastructure ("infrastructure") is truly complex and requires constant and expensive repair and monitoring. Such investments warrant good information systems. In the future, infrastructure information systems will integrate sensors with GIS data systems and water management models. Future water systems will be smarter, having intelligence distributed throughout the network. Such intelligence could eventually be continuously available on line to all categories of users of the web, with the water network performance information displayed at a complexity optimized to suit the user. Physical sizes of future infrastructure will depend more on the requirements of autonomous robots, the collection, transmission and processing of intelligence relating to the network performance, and evolving synthetic pipeline materials and multi-service cable-pipes. Use of local recycling and pressure sewers will permit downsizing of infrastructure.

Four controversial issues are presented:

1. For less unsustainability of urban, suburban and rural communities, future systems will become less dependent on non-renewable

James, W. 2000. "Towards Smart, Benign Urban Water Infrastructure." Journal of Water Management Modeling R206-02. doi: 10.14796/JWMM.R206-02.

(C) CHI 2000 www.chijournal.org ISSN: 2292-6062 (Formerly in Applied Modeling of Urban Water Systems. ISBN: 0-9683681-3-1) 
energy. Energy economy is derived from recycling water as locally as possible.

2. New sanitary collection systems for treating human liquid and solid wastes separately will substantially reduce ecosystem impacts.

3. Even better for ecosystems will be the gradual change of general diet (this impact is not immediately obvious).

4. Logically, a consequence of the pursuit of reduced unsustainability is that the size of the human and its domestic animal populations and their associated water demand and concomitant waste load will have to be managed.

This personal vision includes both (i) what the author imagines might happen under favorable conditions, and (ii) what he hopes will happen. Readers are left to enjoy the exercise of distinguishing between the two.

\subsection{Introduction}

For a start, let us clarify that by infrastructure we mean the basic water facilities, services and installations required for a society to function, including dams, reservoirs, buildings, pipelines, treatment plants, pump stations, sewers, drainage systems etc. In our use of the term, it includes innumerable appurtenances such as gutters, inlets, manholes, and connections in private ownership such as toilets. Quality infrastructure is critical to a region's economic future, quality of life, and productivity because it is essential for our daily activities. In this chapter we deliberately and perhaps confusingly consider the three water infrastructures (water supply, wastewater collection and disposal, and stormwater management) as if they were one.

Also at the outset let us agree that a strictly honest interpretation of sustainability will require that no non-renewable energy be consumed, nor should any water or energy be imported from remote areas, and also no by-products such as chemical contaminants should be exported or accumulated locally. For the population density evident in (say) Chicago, sustainability in the strict sense of the word seems, regrettably, implausible. Politically, the term sustainability seems usually to imply reduced unsustainability though it does not sound so catchy that way. We use the longer term here.

Infrastructure failures are universally topical. Growing metropolitan regions are perceived to struggle to (i) mitigate water impairments and impacts and (ii) provide sufficient water of the quality necessary for regional economic growth and competitiveness. Evidently we covet more growth, so we wish to build a more competitive infrastructure, but with an improved environment, 
rather than an impacted one. Perhaps these objectives are self-contradictory, and will remain unattainable, as they have done since the illustrious Romans or even earlier.

Urban water infrastructure can become unimaginably complex. In Chicago, for example, there are seven water reclamation plants, and 125 local communities owning much of the pipe infrastructure. Chicago is recognized for its innovative infrastructure such as water parks, and The Metropolitan Water Reclamation District of Greater Chicago has built decorative aeration waterfalls in small public parks. Apparently the issues are livelier in Chicago than elsewhere, as a number of serious local, regional, national, and international disputes have arisen. One dispute originated in 1848 with the construction of the Illinois and Michigan Canal to provide navigation. Outbreaks of typhoid during the 1870 s and 1880 s were attributed to lake water, and the Chicago Sanitary and Ship Canal was completed in 1900 to solve contamination, drainage and flooding problems (Espey et al., 1994). In 1910 the North Shore Canal and in 1922 the Calumet Sag Canal were built to facilitate the conveyance of sewage. Flow of the Chicago River was reversed, diverting international water from Lake Michigan into the Illinois and Mississippi River systems. On April 13, 1992 a section of the 100-yr old underground freight tunnel was breached where the tunnel crosses the Chicago River in the downtown area. Utility services to more than 100 buildings in downtown Chicago were lost, several hundred thousand workers were sent home, and the entire subway system and a major expressway in the Loop were shut down (Oberg and Schmidt, 1993). The People of the State of Illinois have been ordered by the U.S. Supreme Court to put back into Lake Michigan an equal number of gallons of water that has been "over-pumped" since 1980. Chicago's central concept, the deep tunnel, after serious scrutiny, is now being said by some to represent society's failed philosophy towards water resources management.

Toronto is implementing its own deep tunnel for flow balancing (Green, 1997). Like other cities, Toronto's 150 -year old sewer system was originally developed as a combined system, whose capacity was soon exceeded, so that basement flooding was a recurrent problem. Storm sewers were constructed in the 1960 s, separating some $70 \%$ of road drainage. Annually 5 million cubic metres of combined sewage overflows from 24 outfalls, resulting in frequent beach closing by the medical officer of health. Now under construction, the new tunnel will reduce overflows to less than one per year at a cost of $\$ 370$ million (1996Cdn\$). Many examples of expensive end-of-pipe facilities exist in North America.

Although impacts will be reduced by this strategy, user behavior will not be required to become better informed (the sources of the problems will not be eliminated). Fundamentally this chapter argues that both our behavior and our infrastructure must become smarter. 


\subsection{Developing Smart Sewers and Pipes}

In the U.S., the $\$ 1.8$ trillion system of drinking water, wastewater, and storm water infrastructure requires constant and expensive repair and monitoring $(\$ 280$ billion over the next 20 years). Investments of this magnitude warrant the very best information systems.

Effectiveness and efficiency are dependent on good information flow as well as effective task assignment. Good decision support and information systems will become widely used and integrated into the water network, and water system administration will be rearranged to fit the new databases and decision support. In some cases infrastructure will itself be laid out to facilitate improved information flow. Water treatment and distribution systems and wastewater treatment plants are becoming highly instrumented and are well advanced over wastewater collection systems. Stormwater drainage clearly lacks computerization, as does the management of receiving waters. In the future all these systems will not only be better instrumented, but also operated and controlled from a unified web-oriented information management system.

Old, existing systems also need updated monitoring equipment. LeFebvre (1988) describes a compliance schedule for planning, design and construction of major permanent improvements to Pump Station 64 in San Diego County, California. Improvements included a parallel force main, pumping capacity expansion, alternate power source and, significantly, sensing devices on all motors, bearings and vibrating components. Extending this idea to all North American infrastructure will create a large market, conceivably installing millions of sensors, to keep watch over us.

Future urban water systems will be smarter, having intelligence distributed throughout the network, and will incorporate many advantages over our current (dumb) systems (James et al., 1993b). The term intelligent drains is coined to mean an urban drainage system retrofitted with real time control designed to support a pollution prevention strategy. Real time control of urban drainage can be designed to reduce the number and duration of overflow events, reduce basement flooding, reduce downstream environmental impacts, and monitor and enforce water quality. Real time control depends on good rain sensors. Highresolution rain data is already available at many North American cities, and provides real advantages for fitting convective storm models to compute spatially- and time-averaged rain rates over the urban area (James and James, 1999).

Such intelligence will be continuously shared on line with all users of the web. Water network performance information will be displayed at optimal complexity for example to managers, water consumers, and general members of the public, such as school classes. Already available are 3-D GIS data systems 
that perform over the web. Public-oriented urban water information systems will counter the "out-of-sight-out-of-mind" attitudes that heretofore have hindered attempts to rationalize investment in water infrastructure systems.

In an anti-technologist call for improved information flow, Roy (1999) demands on behalf of the vast, underrepresented population, the right to information on the planning, financing, building, and operation of infrastructure. In the future, even small communities will share their information with the public, who will take more control of their own water resources and water re-use. Roy firmly blames arrogant and secretive "urban engineers" (this presumably includes the writer) for water infrastructure failures. Not all urban engineers are megalomaniacs - mostly they plan, design, build, operate and refurbish functional infrastructure optimally under severe external constraints imposed by society itself. Clearly engineers should become part of the information flow process.

As a further example of information dissemination, Stockholm has a conspicuous on-line display in a popular public park, depicting the city's present and accumulated discharge of pollutants into the environment - a startling monument to human self-indulgence, and probably in stark contrast to attitudes prevailing among infrastructure administrators in Ontario.

Current engineering approaches that are widely used today for planning, design, operation and control of complex infrastructure have serious shortcomings, including their narrow and simplistic focus (James, 1999). Computer models are an essential part of smart infrastructure. Useful multi-disciplinary models will continue to be developed co-operatively by scholars, researchers and practitioners, and used by state, provincial, federal and municipal officials, and relevant organizations. Because of the complexities of the real situation, models that are integrated, area-wide, and technically correct will become the dominant decision-making tools for infrastructure development, management and optimization. Such models will incorporate engineering, economic and ecological concerns, and interactions between each of them.

Gradilone (1988) describes an early use of geographical information systems (GIS), then termed a geo-coding process, and explains how the geocoded customer database is used for customer service operations, and for distribution main rehabilitation. How right he was! Urban water managers will become entirely dependent on their facilities management information networks: the more complex the system, the more computer dependent it will become.

Burke (1993) discusses an information management system used in Australia and Japan that combines modeling with the integrated management of water, sewerage and storm water infrastructure. Future computer-based support systems will provide comprehensive information management combining engineering, maintenance, accounting, automatic data collection, and impact assessment (Utrecht, 1991). Management will come to rely more and more on computer control in the future. 
In perhaps the most prescient of the publications reviewed here, Nakamura et al. (1995) describe two new composite submarine umbilicals supplying (i) $66 \mathrm{kV}$ power, and fiber optic communications, and (ii) fiber-optic communications and water. Manufactured in continuous lengths of $4.4 \mathrm{~km}$, both were laid below the sea bottom to service construction of the Trans--Tokyo Bay Highway. It is precisely the future use of this technology that will facilitate the intelligent water infrastructure envisioned in this chapter.

There is scope for such innovation. Infrastructure innovation is needed because it benefits both our quality of life and economic prosperity. R\&D goes hand-in-hand with the provision of innovative infrastructure. Research for innovative infrastructure and development and commercialization of innovations has been discussed in three recent reports by the Civil Engineering Research Foundation (CERF, 1993, 1994, 1997). Data from U.S. federal laboratories indicates that public works (which is much more than just water) infrastructure $R \& D$ activity ranged between $\$ 1.026$ and $\$ 1.386$ billion in 1992 , about $1.6 \%$ of total federal R\&D expenditures. However no federal agency has been assigned or taken the lead role, with the result that public works infrastructure R\&D lacks guidance of a comprehensive, coordinated, and integrated national policy. CERF (1993) recommended the cooperative development of a national public works research agenda by federal, state, and local entities, together with the private sector.

In fact, and in the long-term, worldwide demand for innovative infrastructure technologies promises to be strong, and the rapid commercialization, or translation of an idea into a marketable product is critical to maintaining and improving infrastructure. Public dividends include more reliable, more efficient, safer and less costly public facilities and services. Regrettably, the U.S (probably applies equally to Canadian) construction industry is not considered to be a progressive adopter of new technology (CERF, 1997). CERF consequently set up the partnership for the advancement of infrastructure and its renewal between industry, government and academia, to accelerate the comprehensive renewal and advancement of infrastructure towards a "truly sustainable" system (see URL 1 in the list of reference URLs at the end of this chapter).

In a comparative study of European and American R\&D, it was found that the U.S. led in high performance concrete, waste and wastewater treatment, computer-aided design, solid and hazardous waste disposal, global positioning systems (GPS) and GIS technology, and integrated databases (CERF, 1994). Europe on the other hand led in tunneling, and energy conservation (while Japan led in automation, field computer use, safety and building systems). Europeans may soon lead in innovative infrastructure because they lack the concern for liability issues that so plagues North America. In Europe new technology from $\mathrm{R} \& \mathrm{D}$ has a better chance of application in practice, and this encourages positive payback from R\&D investment. Generally in Europe the vision for infrastructure 
innovation springs from the private sector, and European contractors maintain larger R\&D departments than do their American counterparts. The CERF report aims several recommendations at the U.S. federal government to improve U.S. R\&D, based on perceived European advances.

The present writer has noted other, significant differences. Europe charges for local telephone calls, making the web more expensive. Europe has a larger mix of official languages, making communication more expensive. Commercial software costs more in Europe and Japan, so that, at least in their engineering communities, there is an unwillingness to share source code. Population densities in those two places are higher, with the result that their natural water quality is lower than (say) Canada, and they obviously have less space for development.

Europe may be among the leaders in water conservation, Japan in largescale computer control and Canada in building attractive, safe, livable urban areas of high quality. The next section covers technology that is being adopted very slowly, even though its effectiveness has been demonstrated for some time.

\subsection{Intelligent Management of Distributed Storage}

Somewhat analogous to information networks, which distribute information in packages at slacker times to local computer storage, future infrastructure will be designed to serve the particular needs of domestic, commercial, industrial and recreational sectors by using storage distributed around the water network. Storage for the three water systems varies in scale (sanitary smaller than storm water; smaller water tanks and ponds at the point of use, larger for neighborhoods, larger raw water storages for fire-fighting) with size optimized against variability and required volume rate of flow. In this way, networks will operate continuously at near optimal efficiency.

For example, users will abstract potable water from the network into their local storage at times and cost that depend on availability. In these systems a small storage tank and pressure pump is installed in each home, and high peak flows in the distribution network are eliminated. Smaller diameter water mains are required and may be constructed from high-density polyethylene pipes at significantly reduced costs. When local in-line pressure falls in the distribution network, owing for example to a high demand, or a pipe break, water is supplied from storage at or near the point of consumption. Such systems have been designed for the arctic (James and Robinson, 1979), and will likely first find application in special areas where the technology can be effectively managed.

On the wastewater side, smaller-diameter, shallow-buried, low-pressure effluent sanitary sewer systems are similar in concept, and have been shown to be more economical than traditional gravity systems. Many different systems are available commercially. In one application, when pressure in the low-pressure 
sewer network falls, the user's in-line pump delivers effluent from a storage or septic tank to the sanitary collection system, resulting in the delivery of a more constant stream to the treatment plant.

Efficiency depends on sensors, controls and reliable electrical power sources, necessary ingredients of intelligent infrastructure. Intelligence of this type, coupled to weather forecast information, will eliminate combined sewer overflows, at least from hazardous point sources such as hospitals (James et al., 1993a). Weather radar applications are increasing in Japan, and Chicago itself was a pioneer in the application of this technology.

Of course these digital information systems will incur costs that will be charged back. Charging algorithms for computing individual water and sewer rates will change so that the savings from operational efficiencies will be passed back to users. System integration will be another important source of improved efficiency.

\subsection{Integrating the Human Concept of the Four Water Subsystems}

Management structures and their regulations have evolved over the past century from an original condition of plenty, but water availability, quality, consumption and demand have gradually changed.

Modern infrastructure is used for disposal of sanitary products at loads of 5-8 gm per cap-day (Ashley et al., 1999). For Chicago this translates to about 15000 tonnes per year. Females in the $18-44$ yr age group are responsible for $75 \%$ of all sanitary waste flushed down sewers. Items most commonly flushed were tampons (flushed by $79 \%$ of an interviewed cohort), applicators (36\%), sanitary towels $(50 \%)$, panty liners $(32 \%)$, cotton buds $(7 \%)$, cotton wool $(15 \%)$, and condoms $(24 \%)$. Disposing of sanitary waste via the solid stream is more sustainable than the water borne route. Users who understand these benefits as well as those of separating their own bodily waste streams (described in section 2.7 below) will seek appropriate jurisdictions and infrastructure.

Fragmentation by competing government agencies, jurisdictions, and regulations exacerbate the problems (i) of accommodating demand for water, (ii) of preserving water quality, and (iii) of managing storm water flows. Artificial barriers exist between management's views of the three water systems (water supply, wastewater collection and disposal, stormwater management), and these are reflected in different executive departments, perhaps all the way up to the federal cabinet (in Canada). Distinctions in the way that the three sets of planners, designers, constructors and operators work, and those of a related (fourth) infrastructure, pavement (especially permeable), will be eliminated in the future. 
When management of these four currently distinct water infrastructure systems is integrated, the arrangement of the resulting system will show several improvements, for example:

1. local storage and use of storm water and urine for garden watering,

2. recycling of gray water for flushing (URL 2),

3. use of local raw surface water for fire-fighting,

4. treatment of heavily-polluted first flush stormwater,

5. permeable pavement for treating stormwater (Pitt et al., 1998),

6. zero surface runoff ( $100 \%$ groundwater replenishment) from new developments, and

7. aquifer storage and recovery of urban stormwater and recycled water (Dillon et al., undated).

Only after the currently distinct engineering computer models for planning, design and operation of these four systems are integrated seamlessly, can such issues be effectively discussed, and implemented. Some of this is already in hand. Heaney et al., (1998) also view urban stormwater management as a subsystem of watershed management systems, and present results of a literature review with preliminary evaluations of alternative future scenarios.

To summarize this section, because of increasing societal awareness of water infrastructure problems, and because of governmental and non-governmental efforts, cities will improve their legal and institutional structures governing the management of water resources, to better address water as an integrated system. These developments will no doubt require that new infrastructure be built to new physical specifications.

\subsection{Sizes and Layout of Future Infrastructure}

Geometrical details such as minimum diameters, minimum longitudinal radii and maximum runs may change (trenches may be shallower, diameters may be smaller, layout radii and transitions may be smoother, and runs may be longer). Currently, sizing is for human entry and manual maintenance via manholes of e.g. sewer networks. Future sizing and longitudinal geometry will depend more on the requirements of autonomous robots for inspection and repair, and on collection, transmission and processing of intelligence relating to the network performance. Evolving synthetic materials for pipes will reduce costs (Boon, 1996). Autonomous devices for inspection and repair will require smaller manholes and probably larger longitudinal radii (horizontal and vertical curves and transitions).

Several types of autonomous robots for pipeline inspection and repair are available on the market. Larger diameter $(2 \mathrm{~m})$ long-penetration tunnel inspection robots require a maximum distance of $10^{4} \mathrm{~m}$ and small diameter $(150 \mathrm{~mm})$ pipeline robots require a maximum penetration of $300 \mathrm{~m}$ (URL 3 ). 
Many appurtenances such as manholes, bends, drops etc. will be redesigned. For instance, valves on water distribution systems are frequently in a deteriorated state (Federico, 1988). Installed valves will be re-designed to facilitate passage of autonomous inspection and repair devices, and new materials will be used for their fabrication. For the latter reason, for better disease prevention, and for improved distribution security, dead-end mains will be eliminated.

Pressure and vacuum (i.e. the special case where pressure is less than atmospheric) sewer systems require much smaller infrastructure. Concerns relating to transitions between sub- and super-critical flow, which cause technical designs to require large conveyances, do not arise in pressure sewer systems. Pressure sewers have already achieved wide usage in North America, and continue to show cost savings. Moreover they are better suited to the separation of personal human wastes as described in section 2.7 below.

\subsection{Less Unsustainable Water Systems}

"A sufficient quantity of pure and wholesome water" was the rallying cry for development in the mid-19 $9^{\text {th }}$ century (James and James, 1978), and water remains to this day a key to less unsustainable metropolitan communities.

We need to work harder at learning from clever people, wherever they may live. Let us consider the effect of four intellectually challenging issues:

1. renewable energy,

2. separation of urine, feces and extraneous solids,

3. diet, and

4. population management.

Zoreda-Lozano and Cataneda (1998) present a general approach linking urban technologies for water use and sustainable development in Mexico City. They describe a tough situation, advocating among other things new materials, information handling, automation, and miniaturization. For less unsustainable urban, suburban and rural communities, future systems will be designed to use minimum non-renewable energy. Energy economy is derived from recycling water as locally as possible. For instance, stormwater ponds may be used for flushing and fire fighting. Numerous examples exist around the world, especially in regions of water and financial scarcity.

In Sweden a SEK 30 million research program has been initiated collaboratively at eight universities on rendering urban water management sustainable (Malmqvist, 1999). Included in the proposal is a national urban water research school which includes practical on-site training, that will be compulsory for all post-graduate students within the research program, to ensure that they are skilled in broadbased inter-disciplinary water management. 
History shows us that advances in materials have foreshadowed those of infrastructure, and continually reduced its costs. Polyethylene pipes will be used in order to reduce costs, and also to reduce contamination arising from copper and zinc-plated materials.

Lozar (1993) calls for rethinking our definition of infrastructures, and for discarding our old infrastructure paradigms. Advanced infrastructure design should consider environmental management (creating suburban ecologies in neighborhoods), energy conservation (passive and photovoltaic community systems), material recycling (local reuse of materials and systems), automated infrastructure (robots and sensors), advanced communication technology, pollution reduction and quality of life issues. These concerns should and will be integrated into zoning regulations and building codes.

Enforcement of pollution prevention is indeed an effective path to reduced unsustainability. The City of Toronto is moving forward a new sewer use bylaw that requires pollution prevention planning (URL 4). Enforcement of new regulations, virtually eliminating persistent contaminants, will encourage new infrastructure for recycling human waste as sludge to agricultural areas.

\subsection{Sharing our Once-Used Food and Nutrients}

Here we develop a radical theme that could have important benefits to folks who live downstream (i.e. all of us). These ideas are not new: Victor Hugo wrote a piece on the sewers of Paris marvelously entitled The entrails of the leviathon. Esrey and Andersson (1999) are critical of conventional sanitary infrastructure, and call for a change in the concept of wastewater. Three main components of environmental sanitation will drive our actions: pathogens, nutrients and water. Most pathogens come from fecal matter, and most nutrients from urine. Most pathogens need both nutrients and water to survive and reproduce. Hence in the future we will separate at the source the pathogens (feces) from nutrients (urine) and water. We will do so in order to recycle the nutrients, and not the pathogens (today, our infrastructure aids reproduction and distribution of harmful pathogens, and accumulates nutrients in harmful places). Future infrastructure will return nutrients to the land, and isolate pathogens so that the relatively small amount of harmful material can be easily destroyed. Inputs of water and chemicals for treatment will be reduced. Everything will be cycled continuously, the so-called waste streams (really resources in the wrong place) forming beneficial food for fellow living systems. It is not waste that we should dispose of, rather our concept of waste (Esrey and Andersson, 1999).

Otterpohl et al. (undated) also present forthright arguments in favor of managing differentiated water and waste in urban areas. Central to the task of sanitation, besides maintaining the highest hygienic standards, is soil fertility. 
Recall that one person can produce as much fertilizer as is necessary for the food needed by one person. Also, nearly all the required nutrients are in the urine stream. Human feces might be described as once-used food. Modern sanitation has mixed the food and water cycles, with the result that substances of soil fertility are being washed away to receiving waters where they accumulate and are extremely harmful. Inevitably, soil fertility is depleted, and drinking water is contaminated. Future sanitation and waste infrastructure will respect the different qualities of human waste matter. Otterpohl et al. present ten different scenarios, some of which include concepts of distributed storage described briefly in the present chapter.

The most important piece of infrastructure for source control is the personal toilet. New toilets will separate urine from once-used food, since the two components when separated can be recycled safely and economically (Lange and Otterpohl, 1997). It is the fecal matter that contains pathogenic microbiological contaminants and persistent trace contaminants that are effective at extremely low concentrations, such as residues of medicines and their metabolites, or hormones from birth control. More intelligent use of existing sanitary sewers may involve the transport of urine as timed releases or waves. These proposed new systems will reduce COD, $\mathrm{BOD}_{5}$ and total $\mathrm{N}$ by $75 \%$, total $\mathrm{P}$ by $85 \%$ and total $\mathrm{K}$ even more.

In keeping with these concepts, in a group review of a workshop at Hilterfingen in March 1999, Schertenleib (1999) advocates a household centered approach to environmental sanitation. From the point of view of less unsustainable sanitation, for food production and transport, and for closer contact of city dwellers to nature, the sizes and shapes of cities will be better managed. Golf courses will be used for groundwater replenishment. Cities of the future, it is said, will be developed in the shape of stars with green, rural areas between the arms.

As an aside, one cannot help observing that the gradual and widespread change of diet to lower down the food chain (towards vegetable rather than animal products) will result in considerable improvement of rural/agricultural runoff quality. This is simply due to the substantial (up to 90\%) decrease in land required for food production. Impacts are not obvious: agricultural non-point source pollution contributed to rural drainage will decrease commensurately, substantially restoring the assimilative capacity of the nation's rivers. Requirements for waste water and storm water treatment will then change accordingly. Other downstream benefits include reduced requirements for food processing, refrigeration, disinfection, storage, transportation and preparation (and, arguably, public health).

It seems that in the future informed consumers will require less water. Demand management is not considered in these times to be a good issue for promoting local business development, however, and the implications are discussed the next section. 


\subsection{Population and Demand Management}

Grigg (1986) predicts that demand management will become a recognized part of urban water supply management, and may enter wastewater management as well. Water conservation will become institutionalized as good management practice, rather than remain the emotional, environmental issue that in North America it is today still regarded to be.

Concepts of water value as applied by Harvey (1988) to natural resource damage assessment, water service investment decision making, development of water supply strategies and resource allocation policy, will be further developed. Re-allocation or marketing of existing water sources is a very complicated game (Ten Eyck, 1988; Atwater, 1988). It involves teams of planners, water resources engineers, and experts in demographics, natural resource economics, wildlife and ecology, water attorneys, recreation, agricultural engineering, and other disciplines. Teams will be managed by leaders well versed in negotiation skills and who understand difficulties encountered when some players on other teams work under a different agenda. Nevertheless Duecker (1988) advocates water transfers. Canadians may have a different perspective. Readers will readily understand why University curricula for professionals will incorporate more management skills.

Mills and Herring (1995) discuss the interaction of energy, population and sustainable development. Increased availability of economic alternatives, improved health conditions, and sustainable energy supplies have a direct effect on the rate of population growth. Reducing population growth to a sustainable steady-state value is partly a product of improved health and living conditions brought about by informed industrialization.

One could propose that the provision of high quality infrastructure is a prerequisite for a community in harmony with its environment, which leads to a high quality of life, and a stable population. Certainly it could be a factor in Canada's negative natural population growth rate.

Logically, a consequence of the concepts discussed in this chapter is that the size of the human and its domestic animal populations and their associated water demand will at some future time have to be managed. To some extent, limits will be established by what can be supported by local renewable water and energy (or will we never accept limits to growth in a finite world?). Of course, this argument ignores political realities, with its short-term concerns, but could have some implications for large cities, such as metropolitan Toronto. For example, is 2 million not enough? Is further growth really necessary? How could 20 million possibly be better? Surely the natural environment was in better shape when it was only 200 thousand?

Cities have, according to the Worldwatch Institute, become deathtraps, killing people by the tens of thousands in disasters such as earthquakes (not really 
a natural disaster when it is concrete buildings that kill) and floods (also not a natural disaster where indigenous forests have been stripped). Millions of city dwellers lack sanitation, choke on unhealthy air, suffer violent crimes and live in abject poverty. Yet cities continue to grow rapidly. Tokyo has grown $3000 \%$ in this $20^{\text {th }}$ century, and many of our cities in North America have grown even faster. Simplest of all measures would be to advise city dwellers to simply move out. Intending urban migrants will often be safer staying put in the countryside. Interested Web surfers should visit Worldwatch Institute Online at www. worldwatch. org. Worldwatch is a nonprofit public policy research organization dedicated to informing policymakers and the public about emerging global problems and trends and the complex relationships between the world economy and its environmental support systems. Anomolously, after a couple of years' of human catastrophe, next year marks the end of the UN's international decade for natural disaster reduction (visit: www.idndr.org).

Human population densities seem to be all but irreducible (exceptions may exist, such as the population decrease in downtown Detroit, but the experience is universally regarded negatively rather than as an ecological opportunity). One should have qualms about papers like this present chapter. Though they may indeed contain seeds of good ideas, which if implemented, may reduce impairments of receiving waters, the writer fears that the improved water environment will simply be used to further increase human population densities. Root causes of negative impacts invariably stem from inconsiderate human behavior. Ultimately it is our human behaviour that must be corrected and presumably this includes unlimited breeding, and uncontrollable avarice. In the next century these moral issues will have to be resolved.

The fundamental cause of many problems of water systems is urbanization of rural landscapes. Of these the worst problem is loss of natural habitat, which is driven by rapid national and global economic growth, a synonym perhaps for greed. It is a good bet that numerous decision technologies, including macroscopic multi-disciplinary models, will soon be available, claiming to help metropolitan regions simultaneously (i) achieve regional economic goals, (ii) preserve the integrity of surface, ground, and coastal water resources, and (iii) maintain environmental health and bio-diversity. It is also a safe bet that few of these models will include explicit routines covering the benefits of depopulation and negative growth. The web does however contain innumerable innovative ideas, many promoted by the private sector.

\subsection{Privatization}

Privatization supposedly offers municipalities a way to harness private sector resources to improve their infrastructure (Haarmeyer, 1994). Historical reasons for the involvement of the public sector in the provision of infrastructure are 
varied. In medieval times, water and drainage was in private hands. In the recent past, especially following the industrial revolution, government has provided most of the funds for infrastructure, usually as capital for new works.

Reading about the social conditions that led to Government participation is quite salutary. One hopes, with this modern move to privatization, that history will not repeat itself. Caution should be the catchword. Schilling (1988) cautions against funding that favors new construction over rehabilitation of existing systems. Federal, state and local levels of subsidies that influence (i) project size, (ii) project choice, (iii) needs, (iv) finance estimates, (v) decision making, (vi) liability considerations or (vii) that in any other way favor new construction over maintenance and rehabilitation, should be re-evaluated. Failure to provide budget line items for infrastructure operations quickly results in massive accumulated deferred maintenance backlogs.

Insufficient investment in water supply infrastructure poses a public health risk (URL 5). The next few paragraphs list some of the horror stories.

- Annually, 7 million cases of mild to moderate water-related illness occur in the U.S, resulting in 1,200 deaths. In 1993 the USEPA reported that $29 \%$ or more than 16,000 community water systems were not in compliance with the Safe Drinking Water act, and that $20 \%$ of the US population ( 47 million) drink tap water that does not meet EPA-approved standards for microorganisms. This was the same year (1993) that 100 people died and 400,000 were sickened in Milwaukee when the city's water supply was contaminated by cryptosporidium, which is found in $65 \%$ to $95 \%$ of US surface water. Milwaukee subsequently spent $\$ 89$ million to better protect its water.

- The U.S. has an estimated 800,000 miles of water supply pipe, and, according to the American Water Works Association, breaks occur once in every 3.5 miles of pipe.

- Groundwater is tough to clean. Hundreds of municipal wells have been closed because of groundwater contamination. Contaminated groundwater sites number 300,000 to 400,000 , according to a 1994 National Academy of Sciences study. Cleaning them will cost US\$1 trillion (URL6).

Further statistics on infrastructure needs and trends are readily available on the web (e.g. URL 7, URL 8), where one quickly discovers that the amount of money required is mind numbing.

Not unexpectedly, then, existing practice in urban hydrological infrastructure is in certain cases perceived to be failing in its mission. It probably always has and always will, being the difficult, under-valued service that it is. However, innovative infrastructure will continue to effect better stewardship of urban water resources, if management is good enough. 
Grigg (1986) defines good management as management that lacks corruption, displays good manners, and motivates and takes good care of its employees. He felt a decade and a half ago, just as we do now, that cost control will be better in the future. He also writes that life-cycle approaches to capital management will be necessary. Life-cycle design requires planning, management and budgeting for both new and replacement facilities (Shen and Feeser, 1997; Siddiqui and Mirza, 1997). Problems with facilities after they are constructed will be reduced by better quality control in construction.

New partnerships are emerging. Political, economic and business investment climates may need to be further manipulated, in order to bring about the kinds of urban water infrastructure changes suggested. Politicians and investors seem to focus on short-term motives. On the other hand, currently successful infrastructure has useful life expectancies of up to a century or more. How can the case be made to base infrastructure decisions on such long terms? As government yields its role in water infrastructure to the market place, users need to be alert to a possible bias towards undesirable short-term profit objectives such as programmed obsolescence. One suspects that industries are unlikely to support political issues advocating new materials or maintenance systems that could result in reduced business.

In fact, planning and budgeting for infrastructure replacement is a difficult task that has confounded societies from earliest times, and will grow more complex as the inventory of infrastructure grows. Barbolini and McAloon (1988) suggest a method that tabulates the estimated value of infrastructure and its estimated life, and computes expected expenditures. It is a logical and systematic technique for budgeting monetary and human resources and was developed for the Metropolitan Sanitary District of Greater Chicago. Their paper provides examples illustrating how the technique is used for infrastructure replacement and restoration.

Clearly there is a need for infrastructure management to utilize private sector forces and skills more effectively. Build-operate-transfer arrangements satisfy the need to access private sector finance, by permitting privatization in which infrastructure is funded, built and then operated for a defined period by the private sector. The concept is not new in non-water infrastructure, e.g. telecommunications, Terminal 3 in the Toronto International Airport, and the electronic toll route in Toronto.

Walker and Smith (1995) argue that the belief that private initiative can do better than state bureaucracy is now dismantling government monopolies around the world, and has been accredited by institutions such as the World Bank and the United Nations. A build-operate-transfer arrangement for infrastructure procurement is an approach that addresses real fiscal environments surrounding the demand for new and refurbished infrastructure. The basic criterion is that governments, funders and builders must have a transparent formula that ensures 
that the risks involved are placed with those best able to carry and price them. To be economically viable, the revenue generated by the project during the period of concession must be high enough to cover all the costs involved. Costs include initial development, financing, maintenance, operation, an acceptable return to debtors and shareholders, payment of any premium to the host government, and an acceptable profit to the operator. Thus the cost/revenue equation must be considered for the whole life cycle of the concession. This formula satisfies the political, financial and construction demands and ensures that revenues generated by the completed entity satisfy all three.

The approach is still undergoing refinement as the public and private sectors become more aware and proficient with the techniques. Financial models must be constructed with decision analysis tools to test the uncertainty of key variables over the extended life of the project. Then the method can and will be extended to infrastructure rehabilitation. The next section suggests a simple first step.

\subsection{Portfolios of Successful Infrastructure}

Infrastructure failures do seem to be increasingly apparent. Probably infrastructure has always enjoyed a relatively high failure rate, since the public attitude towards infrastructure is such a good example of Hardin's Tragedy of the Commons (URL 9). One suspects that the media promotes the topicality of failing infrastructure, possibly helped by the fact that dramatic video footage is relatively easily obtained. Certainly one portfolio of engineering disasters on the web (URL 10.) attracts a gratifying amount of interest. Possible solutions to our infrastructure challenges could be presented in a portfolio of successful and/or aesthetically pleasing infrastructure, such as that of Geiger and Dreiseitl (1995). The portfolio should include examples recently installed around the world. Several visionary examples of holistic watershed management, and facilities that encourage sustainability values, have recently been developed in North America. They include urban developments that restore cold water fisheries, and storm water detention systems designed for recreational catch-and-release fishing, and/or bird watching. Web sites of such portfolios designed to stimulate public discussion (such as URL 11), will become part of an urban region's strategy for reducing ecological unsustainability.

\subsection{Conclusions}

Future changes could feasibly result in a higher level of economic and ecological stewardship of built and natural water resources. New attitudinal changes to water infrastructure that will make life in future mega-cities somewhat less 
unsustainable. This chapter explores a personal vision of infrastructure, in which we will change many things that affect of infrastructure - most notably we will:

1. Face up to the fact that in a growth-oriented world, true sustainability is a pipe dream.

2. Not distinguish between the human management of the four component water infrastructures.

3. Modify our quest for unlimited growth.

4. Reduce our dependence on end-of-pipe solutions.

5. Build integrated computer-based infrastructure information and control systems.

6. Share this information by publicly posting it on the web. Display the information at user-optimized complexity.

7. Facilitate innovative infrastructure with better management.

8. Make intelligent use of distributed storage.

9. Build macroscopic models.

10. Use autonomous robots.

11. Use pressure sewers.

12. Understand the true nature of our bodily wastes.

13. Treat urine separately from feces.

14. Separate personal sanitation items from sewers.

15. Recycle water locally.

16. Use renewable energy.

17. Enforce pollution prevention.

18. Gradually adopt diets lower on the food chain.

19. Eat food grown in soil fertilized by human feces and urine.

20. Return some agricultural land to the natural state.

21. Manage human and animal populations.

22. Eliminate water transfers.

23. Publicize successful, aesthetically pleasing infrastructure.

24. Learn from regions of financial and water scarcity.

25. Privatize the infrastructure business.

26. Restore cold-water fisheries.

27. Create wild life values in cities.

28. Rearrange financial priorities to favor infrastructure maintenance.

Visions generally comprise both wistful dreams of what could be as well as guesses at what will be. It is up to the reader of this chapter to critically discriminate between concepts that are plausible or implausible, possible or impossible, probable or improbable. 


\section{Reference URLS}

1. www.asce.org/govnpub/execsum.html

2. http://clivusmultrum.com/greywater.html

3. www.Aquaticsciences.com/tunnel.htm

4. www.city.toronto.on.ca/wpc/nbylaw.htm

5. www.asce.org/govnpub/issbrfdw.html

6. www.asce.org/govnpub/issbrfww.html

7. www.eps.gov/ogwdw/needs/stateinfo.html

8. www.epa.gov/oppeinet/oppe/awl/water/h2over/intro.txt.html

9. http://dieoff.org/page95.htm

10. www.eos.uoguelph.Ca/webfiles/james/homepage/Teaching/ FamousEngrgDisasters.htm

11. www.eos.uoguelph.ca/webfiles/james/homepage/Teaching/ wjaesthetics.htm

12. www.wsscc.org/vision21/docs/doc39.html.

13. www.wsscc.org/vision $21 /$ docs/doc08.html.

14. www.wsscc.org/vision21/docs/doc09.html.

\section{References}

Ashley, R.M., Dunkerley, S.H., Souter, N., Blackwood, D.J., Moir, J., Davies, J., Cook, A., Butler, D. 1999. Domestic sanitary waste disposal: sustainability of alternative strategies. Research progress report, Towards Sustainable Cities Grant program. Available form the principal author. $7 \mathrm{pp}$.

Atwater, R. W. 1988. Water marketing in California. In: Infrastructure and marketing in water resources. Pub. by ASCE. ISBN 0-87262-657-1. Pp. 43-46.

Barbolini, R. R. and McAloon, T. J. 1988. Planning for infrastructure rehabilitation and replacement. In: Infrastructure and marketing in water resources. Pub. by ASCE. ISBN0-87262-657-1.Pp. 8-16.

Boon, J. 1996. Thermopipe - a new potable water pipeline renovation technology. Pipes and pipelines International. Feb. 1996. p 35-38.

Burke, P. 1993. Infrastructure management information systems past, present and future. Proc $2^{\text {nd }}$ Australasian conf on computing for the water industry today and tomorrow. Instn of Eng'rs Australia. p 161-165.

CERF (Civil Eng'rg Research Fndn). 1993. Federal public works infrastructure $R$ and D: a new perspective. Report 93-EF1003. Oct. 1993. 77 pp.

CERF (Civil Eng'rg Research Fndn). 1994. Constructed civil infrastructure systems R and D: a European perspective. Report 94-5010. Oct. 1993. 
CERF (Civil Eng'rg Research Fndn). 1997. Commercializing infrastructure technologies: a handbook for innovators. Report 97-5028. Oct. 1993. 77 pp.

Dillon, P., Pavelic, P., Martin, R. and Gerges, N. (undated). Aquifer storage and recovery of urban stormwater, recycled water and mains water: old principle, new technique. Manuscript available from the principal author at: peter.dillon@adl.clw.csiro.au

Duecker, L. L. 1988. The goose that lays the golden eggs. In: Infrastructure and marketing in water resources. Pub. by ASCE. ISBN 0-87262-657-1. Pp. 47-52.

Espey, W. H., Lara, O. G., and Barkau, R. L. 1994. Lake Michigan diversion at Chicago. Procs. ASCE National Conf. on Hydraulic Eng'rg, ASBN 0-7844-0037-7. p175-181.

Esrey, S., and Andersson, I. 1999. Environmental sanitation from an ecosystems approach. Paper 9, Vision 21- water for the people. Water supply and sanitation collaborative council. $8 \mathrm{pp}$. See URL 12

Federico, P. 1988. Distribution system rehabilitation. In: Infrastructure and marketing in water resources. ASCE. ISBN 0-87262-657-1. p. 4-7.

Geiger, W. and Dreiseitl, H. 1995. Neue wege fur das regenwasser: handbuch zum ruckhalt und zurversickering von regenwasser in baugebieten. Oldenbourg. ISBN 3-486-26259-9.302pp.

Gradilone, F. 1988. Inexpensive geo-coding for water utilities. In: Infrastructure and marketing in water resources. Pub. by ASCE. ISBN 0-87262-657-1. Pp. 17-22.

Green, W. 1997. "City of Toronto Experience: the Process of Environmental Approval for the Western Beaches Storage Tunnel." Journal of Water Management Modeling R195-14. doi: 10.14796/JWMM.R195-14.

Grigg, N. S. 1986. Urban water infrastructure - planning, management and operations. John Wiley. ISBN 0-471-82914-5.340 pp.

Haarmeyer, D. 1994. Privatizing infrastructure: options for municipal systems, Journal AWWA, March 1994. p 42-55.

Harvey, E. F. 1988. Emerging applications of water valuation. In: Infrastructure and marketing in water resources. Pub. by ASCE. ISBN 0-87262-657-1. Pp. 25-34.

Heaney, James P.; Wright, Leonard; Sample, David 1998. Innovative wet-weather flow management systems for newly urbanizing areas. Proc 25th Annual Conf on Water Resources Planning and Management Jun 7-10 1998 Chicago, IL, ASCE Reston VA. p 325-330

James, W. 1994. On reasons why traditional single-value, single-event hydrology (typical design storm hydrology) has become simple-minded, dishonest and unethical. Invited paper. US Army Corps of Engineers Hydrologic Eng'rg Center. Workshop on Urban Hydrology and Hydraulics Models, Davis, CA. Report SP26. pp.169-181

James, W. and James, E.M., 1978. A Sufficient Quantity of Pure and Wholesome Water, Phelps Publishing Co., London, Ontario. Sept 1978. 150 pp. ISBN 0-9697422-2-3

James, W. and James, W. R. C. 1999. Integration of design models with GIS, the web and group decision support. CSCE 14th Canadian Hydrotechnical Conference, Regina, Saskatchewan. June 2-5, 1999.

James, W., Kezys, V., and Torlaschi, E. 1993a. Intelligent Drains: Urban Surface Water Pollution Control Using Radar, 1993 Joint CSCE-ASCE National Conf. on Environmental Engr'g, Montreal, pp 1599-1606.

James, W., Nimmrichter, P., and Young, B.C. 1993b. Towards Intelligent Drains. 6th Int. Conf. on Urban Storm Drainage, Niagara Falls, ON, Sept 12-17 1993. pp 1369-1374. 
James, W. and Robinson, M.A., 1979. Water Distribution Pipe Networks for Arctic Settlements, Symposium on Utilities Delivery in Northern Regions, Report EPS 3wp-80-5, Edmonton, Alberta, pp. 347-363.

Lange, J. and Otterpohl, R. 1997. Abwasser: handbuch zu einer zukunftsfahigen wasserwirtschaft. Pub by MALL-BETON. ISBN 3-980352-1-5. 225 pp.

LeFebvre, F. 1988. Renewing San Diego Pumping Station No. 64. In: Infrastructure and marketing in water resources. Pub. by ASCE. ISBN 0-87262-657-1. Pp. 23-24.

Lozar, C.C. 1993. Advanced technology proposals for infrastructure rebuilding for sustainable development. Proc of the infrastructure planning and management conf. ASCE. ASBN 0-87262-917-1.p 217-221.

Malmqvist, P-A. 1999. Sustainable urban water management. Vatten (Sweden) 55:7-17.

Mills, J.I., and Herring, J.S. 1995. Interaction of energy, population and sustainable development. Proc $30^{\text {th }}$ Intersociety energy conversion Eng'rg conf. ASME. p 403408.

Nakamura, Y., Kuroshima, T. and Takeuchi, M. 1995. Installation of $66 \mathrm{kV}$ power-optical fiber composite submarine cable and water pipe for the Trans-Tokyo Bay highway. IEEE Trans. on power delivery. 10(3):1156-1167.

Oberg, K.A., and Schmidt, A.R. 1993. Water-level, velocity and dye measurements in the Chicago tunnels. Procs. ASCE National Conf. on Hydraulic Eng'rg, ASBN 08262-920-1.p 1476-1481.

Otterpohl, R., Albold, A. and Oldenburg, M. (undated). Differentiating management resource of water and waste in urban areas. Manuscript available from the principal author at otterwasser@t-online.de

Pitt, R., Lilburn, M., Durrans, S.R., Burian, S., Nix, S., Voorhees, J. and Martinson, J. 1998. Guidance manual for integrated wet weather flow collection and treatment systems for newly urbanized areas. Final draft report. USEPA wet weather flow program, Edison, NJ.

Roy, B. 1999. Rural community vs. urban engineer. Paper 8 , Vision 21 - water for the people. Water supply and sanitation collaborative council. 5 pp. See URL 13.

Schertenleib, R. 1999. Household-centered environmental sanitation. Draft report of the Hilterfingen workshop, Vision 21- water for the people. Water supply and sanitation collaborative council. 6 pp. See URL 14

Schilling, K.E., 1988. Review of the Nation's water resources infrastructure needs. In: Infrastructure and marketing in water resources. Pub. ASCE. ISBN 0-87262-657-1. p.1-3.

Shen, Y-C., and Feeser, L.J. 1997. Life-cycle design approach to sustainable development of civil infrastructure. Proc $4^{\text {th }}$ congress of computing in civil engn'rg. ASCE. p511-518.

Siddiqui, S., and Mirza, M.S. 1997. Infrastructure for sustainable development. Proc Annual Conf, CSCE p 291-300.

Ten Eyck, G. S. 1988. Solutions to Institutional constraints in water marketing. In: Infrastructure and marketing in water resources. Pub. by ASCE. ISBN 0-87262-6571. Pp. 35-42.

Utrect, J.K. 1991. GIS infrastructure management and maintenance applications of the future. $2^{\text {nd }}$ Nat. specialty conf. on civil Eng'rg applications of remote sensing and GIS. ASCE. ASBN 0-87262-832-9.p 173-178. 
Walker, C. and Smith, A. J. (Eds.) 1995. Privatized infrastructure - the BOT approach. Thomas Telford Pubs. ISBN 0-7277-2053-8. 270 pp.

Zoreda-Lozano, J. J., and Castaneda, V. 1998. Critical issues in urban technologies for sustainable development: the case of water infrastructure in Mexico City. Policy Studies Review, Summer/Autumn 1998 15:2/3 pp157-169. 